\title{
Application of an endo-xylanase from Aspergillus japonicus in the fruit juice clarification and fruit peel waste hydrolysis
}

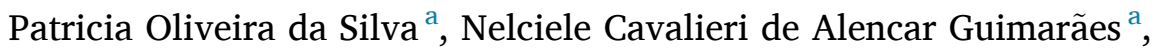 \\ John Dayvan Maidana Serpa ${ }^{\text {a }}$, Douglas Chodi Masui ${ }^{a}$, Clarice Rossatto Marchetti ${ }^{a}$, \\ Newton Valerio Verbisck ${ }^{\mathrm{b}}$, Fabiana Fonseca Zanoelo ${ }^{\mathrm{a}}$, Roberto Ruller ${ }^{\mathrm{a}}$, \\ Giovana Cristina Giannesi ${ }^{\text {a,* }}$ \\ ${ }^{a}$ Laboratory of Biochemistry and Microorganisms, Federal University of Mato Grosso of Sul, Campo Grande, MS, Brazil \\ ${ }^{\mathrm{b}}$ Embrapa Gado de Corte, Campo Grande, MS, Brazil
}

\section{A R T I C L E I N F O}

\section{Keywords:}

Endo-xylanase

Purification

Aspergillus sp.

Fruit juice clarification

\begin{abstract}
A B S T R A C T
The endo-xylanase from Aspergillus japonicus (UFMS 48.136) was purified in a single step using carboximethylcellulose chromatographic column and applied in fruit juice clarification process and fruit peel waste hydrolysis. This purification procedure resulted in 38.9-fold purification of endo-xylanase with $83.3 \%$ final yield. MALDITOF analysis confirmed the molecular mass of $32 \mathrm{kDa}$. The optimal purified endo-xylanase activity was a range of $\mathrm{pH}$ from 5.0 to 6.0 and from 50 to $60 \mathrm{C}$, retaining more than $70 \%$ of its activity at all pH studied (3.0-8.0) for $24 \mathrm{~h}$ at room temperature. The A. japonicus endo-xylanolytic activity stimulation curve was assayed in the presence of different birchwood xylan concentrations (ranging from 0.02 to $0.5 \% \mathrm{w} / \mathrm{v}$ ) and the endoxylanase activity presented a Vmax of $467.4 \quad 30.38 \mu \mathrm{mol} / \mathrm{min} / \mathrm{mg}$, with a $\mathrm{km}$ of $2.59 \quad 0.17 \mathrm{mg} / \mathrm{mL}$, a $\mathrm{kcat}$ of $253.9516 .51 \mathrm{~s}^{1}$ and a kcat/km value of $98.05 \quad 4.41 \mathrm{~mL} \mathrm{~s}^{1} \mathrm{mg}{ }^{1}$. The endo-xylanase was activated by $\mathrm{Mn}^{2}$ (34.5\%) and inhibited by $\mathrm{Cu}^{2}$ (56.9\%). The endo-xylanase was activated by $\beta$-mercaptoethanol, Triton X100, Tween-20, Tween-80 and ferulic acid. In the clarification assay, endo-xylanase successfully clarified the juices of mango (51.11\%), banana (9.99\%) and tangerine (8.54\%). Furthermore, the enzyme also hydrolysed all fruit peel wastes that were tested. In summary, A. japonicus endo-xylanase showed potential for applications in fruit juice clarification and in the treatment of fruit peel wastes, and it is a good candidate for the food industry due to its wide $\mathrm{pH}$ stability under acidic conditions.
\end{abstract}

\section{Introduction}

Xylan is a major structural component of plant cell walls and its degradation requires the action of several enzymes, among which endoxylanases (EC 3.2.1.8) play a key role (Polizeli et al., 2005; Fortkamp and Knob, 2014). Xylanases occur widely in bacteria, yeasts and fungi. Many reports on xylanases from Aspergillus sp., Trichoderma sp., Bacillus sp., Streptomyces sp. and other microorganisms are available (Sharma, 2017). Filamentous fungi are particularly useful producers of xylanases from an industrial point of view because they excrete larger amounts of xylanolytic enzymes into the medium than yeast or bacteria (Polizeli et al., 2005). Microbial xylanases have fascinated researchers because of their potential applications in various industrial processes, being potentially employed in the production of hydrolysate from agro-industrial wastes, as a food additive in poultry, and increasing animal feed digestibility, thereby improving both weight gain and feed conversion efficiency (Polizeli et al., 2005; Amita et al., 2006). Redgwell et al. (2001) reported a constant decrease in the viscosity of wheat flour batter using crude xylanase. Other industrial applications include the use of xylanases as kraft pulp bleaching agents (de Alencar Guimarães et al., 2013; Guimarães et al., 2013; Silva et al., 2015a; Walia et al., 2017; Wu et al., 2018), in orange peel hydrolysis (Uday et al., 2017) and in the clarification of wines and juices (Dhiman et al., 2011; Rosmine et al., 2017; Sharma, 2017). In the food industry, the main desirable biochemical properties for xylanases are optimal activity and high stability at acidic pH values (Polizeli et al., 2005). When xylanases are used along with amylases, pectinases and cellulases, they improve juice production yield by liquefying the fruit, reducing its viscosity,

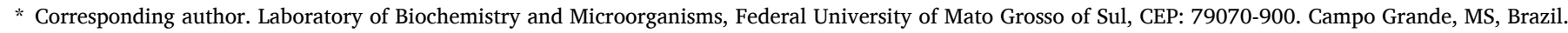

E-mail address: giannesigiovana@hotmail.com (G.C. Giannesi).
} 
stabilizing the fruit pulp and increasing the recovery of aromas. Low-viscosity juices with high clarity are more attractive to consumers and are more nutritive. Increases in clarity and decreases in viscosity of fruit juices using xylanases have been reported by Bacillus stearothermophilus (Dhiman et al., 2011), Bacillus pumilus SV-85S (Nagar et al., 2012) and Streptomyces sp. (Rosmine et al., 2017). Additionally, xylooligosaccharides obtained by xylan enzymatic hydrolysis are important ingredients for the development of novel functional foods due to their prebiotic effects and association with the reduction of blood glucose and cholesterol, a reduction of pro-carcinogenic enzymes, an enhancement of mineral absorption and stimulation of the immune system (Samanta et al., 2015). Endo-xylanases also play a key role in the production of high-value xylooligosaccharides as prebiotics derived from agricultural by-products and other low-cost raw material (Linares-Pasten et al., 2018). The aim of this study was to purify an endo-xylanase produced from wheat bran in a single step and to characterize and employ the enzyme in the clarification of fruit pulps and hydrolysis of fruit peel wastes.

\section{Materials and methods}

\subsection{Microorganism, growth conditions and enzyme production parameters}

The filamentous fungus A. japonicus (UFMS 48.136) was collected and isolated from the Natural Heritage Private Reserve (RPPN) soil of the Universidade Federal de Mato Grosso do Sul (UFMS), Campo Grande (MS)-Brazil. The identification of the fungus was performed using morphological characteristics by the UFMS mycology technician MSc Clarice Rossato Marchetti. The species was deposited in the UFMS mycology collection under number UFMS 48.136. It was cultivated on Potato-Dextrose-Agar (Himedia, IND) and preserved in silica gel. The A. japonicus endo-xylanase production was started using conidia that were suspended in sterile distilled water; the concentration was adjusted to $110^{6}$ spores $/ \mathrm{mL}$, and a volume of $1 \mathrm{~mL}$ of this suspension was used as inoculum. The optimal fermentation conditions, such as carbon source and growth time (stationary or agitated) that would maximize endo-xylanase production were previously determined by OFAT (onefactor-at-a-time) methodology (Guimarães et al., 2013). Cultures were prepared in Erlenmeyer flasks $(500 \mathrm{~mL})$ containing $100 \mathrm{~mL}$ of liquid medium (Rizzatti et al., 2001) with $1 \% \mathrm{NH}_{4} \mathrm{H}_{2} \mathrm{PO}_{4} ; 0.3 \% \mathrm{KH}_{2} \mathrm{PO}_{4}$; $0.24 \% \mathrm{MgSO}_{4} \cdot 7 \mathrm{H}_{2} \mathrm{O} ; 0.45 \%$ yeast extract; $0.02 \%$ peptone and $1 \%$ wheat bran as carbon source $(\mathrm{w} / \mathrm{v})$, maintained at $30 \mathrm{C}$ for $96 \mathrm{~h}$ under static conditions. The medium was subsequently vacuum-filtered using filter paper (Whatman $\mathrm{n}^{\circ} 1$ ) and the filtrate was used as a crude extract source rich in endo-xylanolytic activity.

\subsection{Endo-xylanase assay and protein determination}

Endo-xylanase activity was determined by incubating enzyme samples with $1 \%(\mathrm{w} / \mathrm{v})$ birchwood xylan (Sigma-Aldrich, USA) at $50 \mathrm{C}$ in McIlvaine buffer, containing a mixture of $0.1 \mathrm{M}$ citric acid $(10.3 \mathrm{~mL})$ and $0.2 \mathrm{M}$ disodium hydrogen phosphate $(9.7 \mathrm{~mL}$ ) to obtain $\mathrm{pH} 5.0$ (McIlvaine, 1921). At suitable intervals, the reaction was interrupted with 3 , 5-dinitrosalicylic acid (DNS) reagent (Merck, DEU) and the amount of released reducing sugars was quantified by the methodology according to Miller (1959) using a standard curve of xylose. One unit of activity (U) was defined as the amount of enzyme capable of releasing $1 \mu \mathrm{mol}$ of reducing sugars per minute. Protein (crude extract and purified enzyme) was determined by the Lowry method (Lowry et al., 1951) using the bovine serum albumin as a standard. The specific activity was expressed by the relation between enzyme activity and protein content $(\mathrm{U} / \mathrm{mg}$ protein).

\subsection{Purification of endo-xylanase}

The crude extract rich in endo-xylanase was dialysed overnight in $50 \mathrm{mM}$ sodium acetate buffer ( $\mathrm{pH} 4.5)$ and applied to a CM-cellulose chromatography column $(2.0 \quad 6.0 \mathrm{~cm})$ that was pre-equilibrated with the same buffer. The column was then washed with $150 \mathrm{~mL}$ of this buffer, and a volume of $300 \mathrm{~mL}$ of a $0-1 \mathrm{M} \mathrm{NaCl}$ gradient was applied to elute the proteins that were adsorbed on the resin. The protein fractions collected from the chromatography column were detected by reading the absorbance at $280 \mathrm{~nm}$, and the fractions showing high endo-xylanase activity were pooled and dialysed against deionized water for $24 \mathrm{~h}$. The sample was then used for purity analysis, biochemical characterization, fruit juice clarification and hydrolysis of fruit peel wastes.

\subsection{SDS-PAGE of crude extract and purified endo-xylanase}

The crude extract and the purified endo-xylanase were evaluated by $12 \%$ sodium dodecyl sulphate-polyacrylamide gel electrophoresis as described by Laemmli (1970) to verify homogeneity and the endo-xylanase molecular mass. Protein bands $(17 \mu \mathrm{g})$ were visualized by a silver stain kit (Sigma-Aldrich, USA). Prestained protein marker (Kaleidoscope, Bio-Rad) was used.

\subsection{MALDI-TOF mass spectrometry}

The CM-cellulose chromatographic fraction containing endoxylanase was desalted and concentrated with acetone (1:1) and then applied to a C18 Zip-Tip (Millipore), according to the manufacturer's instructions, prior to MALDI-TOF analysis. The peptide mass fingerprint was obtained after in-gel digestion with trypsin (Promega) (Jimenez et al., 2001). The samples were mixed 1:1 with the indicated matrices (Sigma-Aldrich), and spectra were acquired in positive mode on an Autoflex III Smartbeam (Bruker Daltonics). Mass calibrants ranging from 757.3 to 66.430 Da (Sigma-Aldrich) were used for external calibration, and spectra were processed with Flex Analysis 3.3 software (Bruker Daltonics) and the MASCOT website (Matrix Science).

\subsection{Genomic DNA extraction, PCR and sequencing}

Mycelia of 3 days of culture was collected by filtration and homogenized in liquid nitrogen. Next, genomic DNA was extracted from the mycelia using a Wizard Genomic DNA Purification Kit (Promega-USA) according to the manufacturer's instructions. PCR was used to amplify the internal transcribed spacer regions ITS1-5.8S-ITS2 (ITS1 and 4) of the rRNA gene cluster using two primer pairs: ITS1 (5' -TCCGTAGGTGAACCTGCGG- $\left.3^{\prime}\right)$ and ITS4 (5' -TCCTCCGCTTATTGATATGC- $3^{\prime}$ ) (Druzhinina et al., 2005). The PCR amplification of the ITS regions was performed according to Druzhinina et al. (2005) and Raja et al. (2017). Amplified product sequencing was performed by Sanger technology in a 3500 Genetic Analyzer sequencer (Applied Biosystems).

\subsection{Characterization of the purified endo-xylanase}

\subsubsection{Optimal $\mathrm{pH}$ and temperature}

The optimal $\mathrm{pH}$ of the purified endo-xylanase was determined at $50 \mathrm{C}$ using McIlvaine buffer incubating the enzyme at different $\mathrm{pH}$ ranging from 3 to 8 . The endo-xylanase optimal temperature was measured by incubating the reaction mixtures at different temperatures $(40-80 \mathrm{C})$ with McIlvaine buffer at $\mathrm{pH}$ 5.0. The relative activity was calculated as a percentage of the maximal activity.

\subsubsection{Stabilities under different temperature and $p H$}

The stability under different temperatures were assessed by incubating for $6.0 \mathrm{~h}$ the endo-xylanase by A. japonicus in McIlvaine buffer $\mathrm{pH}$ 5.0 (in the absence of substrate) under temperatures of 40, 45, 50 and 
Table 1

Endo-xylanase purification from Aspergillus japonicus crude extract.

\begin{tabular}{|c|c|c|c|c|c|c|}
\hline Step & Volume (mL) & Total Activity (total units) & Protein (total mg) & Specific activity (U/mg protein) & Yield (\%) & Purification fold \\
\hline Crude Extract & 300 & 2700 & 234 & 11.5 & 100 & 1 \\
\hline CM-Cellulose & 300 & 2250 & 5 & 448.8 & 83.3 & 38.9 \\
\hline
\end{tabular}

55 C. Aliquots were taken at intervals from 10 to $240 \mathrm{~min}$ and subjected to determination of endo-xylanase activity. The $\mathrm{pH}$ stability was determined by incubating for $24 \mathrm{~h}$ the purified endo-xylanase by A. japonicus, in appropriate McIlvaine buffer, under different $\mathrm{pH}$ (from 3.0 to 8.0) at room temperature. Aliquots were taken at 1, 2, 4 and $24 \mathrm{~h}$ intervals and the endo-xylanase activity was determined. The assays were as described in item 2.2 and these results were expressed as relative activity, which is calculated as a percentage of the maximal activity.

\subsubsection{Substrate specificity and hydrolysis products analysis in thin layer chromatography}

Endo-xylanase specificity was verified by assaying the activity against $1 \%(\mathrm{w} / \mathrm{v})$ birchwood xylan, carboxymethyl cellulose (CMC), avicel and starch prepared in McIlvaine buffer pH 5.0 at 50 C, and endoxylanase activity was measured as described in item 2.2. Thin layer chromatography (TLC) was performed using a solvent system containing ethyl acetate: acetic acid: formic acid: water (9:3:1:4 per vol.). The compounds formed by the endo-xylanase action on $1 \%(\mathrm{w} / \mathrm{v})$ birchwood xylan substrate were detected by spraying the TLC with a solution of $\mathrm{H}_{2} \mathrm{SO}_{4}$ and methanol (1:9 per vol.) that contained $0.2 \%$ orcinol, followed by heating at $100 \mathrm{C}$.

\subsubsection{Effect of metal ions, ethylenediaminetetraacetic acid (EDTA) and} various substances on endo-xylanase activity

The relative activity of the purified endo-xylanase was evaluated in the presence of the ions $\mathrm{Ba}^{2}, \mathrm{Ca}^{2}, \mathrm{Cu}^{2}, \mathrm{Co}^{2}, \mathrm{Fe}^{3}, \mathrm{~K}^{2}, \mathrm{Mg}^{2}, \mathrm{Mn}^{2}$, $\mathrm{NH}^{4}, \mathrm{Zn}^{2}$ and EDTA, in concentrations of 1 and $5 \mathrm{mM}$, under the conditions established in item 2.2. The effect of various substances on the endo-xylanase activity was measured by incubating the enzyme samples at $25 \mathrm{C}$ for $30 \mathrm{~min}$ with phenolic compounds (vanillin, ferulic acid, cinnamic acid, 4-hydroxybenzoic acid, coumaric acid, tannic acid) at $1 \mathrm{mg} / \mathrm{mL}$ final concentration. Additionally, 10\% detergents (Triton X100, Tween-20, Tween-80, SDS), 10\% organic solvents (acetonitrile, butanol, acetone, isopropanol, methanol, DMSO, ethanol) and reducing agents ( $\beta$-mercaptoethanol 0.01 and $0.1 \mathrm{M}$ ) were tested.

\subsubsection{Kinetic parameter determination}

The kinetic parameters, Michaelis-Menten constant $(\mathrm{Km}, \mathrm{mg} / \mathrm{mL})$ and the maximum reaction rate (Vmax, $\mu \mathrm{mol} / \mathrm{min} / \mathrm{mg}$ ), were calculated using the software SigrafW, which fits the experimental data to the Hill equation by nonlinear regression (Leone et al., 2005). The A. japonicus endo-xylanolytic activity stimulation curve was assayed in different birchwood xylan concentrations (ranging from 0.02 to $0.5 \% \mathrm{w} / \mathrm{v}$ ). The kinetic experiments were repeated in triplicate, using three different homogenates, and each enzymatic assay was performed in duplicate. The kinetic parameters are presented as the mean SD of the values calculated for the three replicates (n 3 ).

\subsubsection{Fruit juice clarification and hydrolysis of fruit peel wastes by endo-} xylanase of $A$. japonicus

The fruits used for the clarification assays were pineapple, banana, mango, orange, tangerine, nectarine, peach and tangelo. All fruits were acquired from markets and were washed, peeled and macerated using a blender to obtain the pulp. The pulp and enzyme (1:1) were incubated at $55 \mathrm{C}$ for $4 \mathrm{~h}$. After this period the samples were boiled for $5 \mathrm{~min}$ for enzyme inactivation and centrifuged at $21,000 \mathrm{~g}$ for $15 \mathrm{~min}$. The supernatant (juice) was used for determining juice clarity by recording transmittance at $650 \mathrm{~nm}$, taking distilled water as the blank. For each

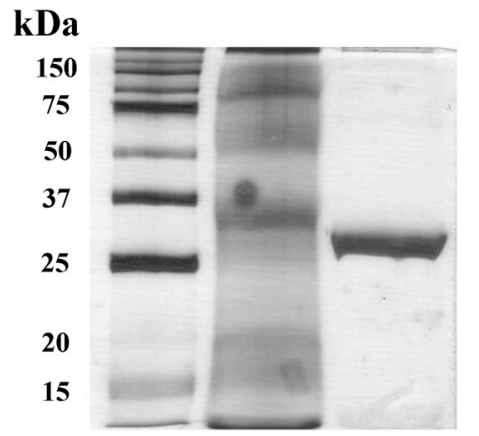

Fig. 1. Purified xylanase SDS-PAGE (12\%). Line 1: Molecular mass marker; Line 2: Crude extract; Line 3: Purified enzyme. Protein bands were visualized by a silver stain kit (Sigma-Aldrich, USA).

fruit pulp, a control was carried out using the fruit pulp and distilled water $(1: 1 \mathrm{v} / \mathrm{v})$. Clarification was calculated as follows:

\% Clarification $\frac{\mathrm{Tt} \mathrm{Tc}}{\mathrm{Tc}} \times 100$

(Tt transmittance of test; Tc transmittance of control), as described by Rosmine et al. (2017). The eight peel wastes obtained from the fruits were dried, milled and weighed and used to determine the biomass hydrolytic potential of the purified endo-xylanase. The separate fruit peels $(5 \mathrm{mg}$ ) were incubated with the enzyme for $15 \mathrm{~min}$ and the amount of released reducing sugars was determined by the methodology according to Miller (1959).

\section{Results and discussion}

\subsection{Purification and identification of the endo-xylanase from A. japonicus and its genomic identification}

Aspergillus japonicus is considered a non-pathogenic fungus in the food industry, as reported in the literature (O'Toole et al., 2006), and is widely used as a producer of enzymes of industrial interest like pectinase, cellulase and xylanase (Li et al., 2015). The endo-xylanase produced by A. japonicus grown on wheat bran was purified from the cell-free culture supernatant. Crude extract $(300 \mathrm{~mL})$ containing the extracellular enzyme was applied to a CM-cellulose chromatography column pre-equilibrated with $50 \mathrm{mM}$ sodium acetate buffer $\mathrm{pH}$ 4.5. The fractions containing high amounts of purified endo-xylanase were eluted with a linear gradient of $0-1.0 \mathrm{M} \mathrm{NaCl}$, resulting in a 38.9-fold purification with $83.3 \%$ recovery. A summary of the purification procedures is presented in Table 1 . There are few examples in the literature where fungal xylanases from mesophilic strains were purified using a single-step purification strategy (Sandrim et al., 2005; Yegin, 2017). Generally, different purified enzymes are commonly used in the fine chemistry and pharmaceutical industries to obtain highly pure products with an increased value. A pure enzyme preparation can prevent other undesirable reactions that could be promoted by contaminant enzymes and metabolites from crude extracts, decreasing the costs for the final product separation. To obtain a purified catalyst, additional techniques can be expensive and make the process unfeasible. Thus, a simple method to obtain purified xylanase is desirable and can reduce the 


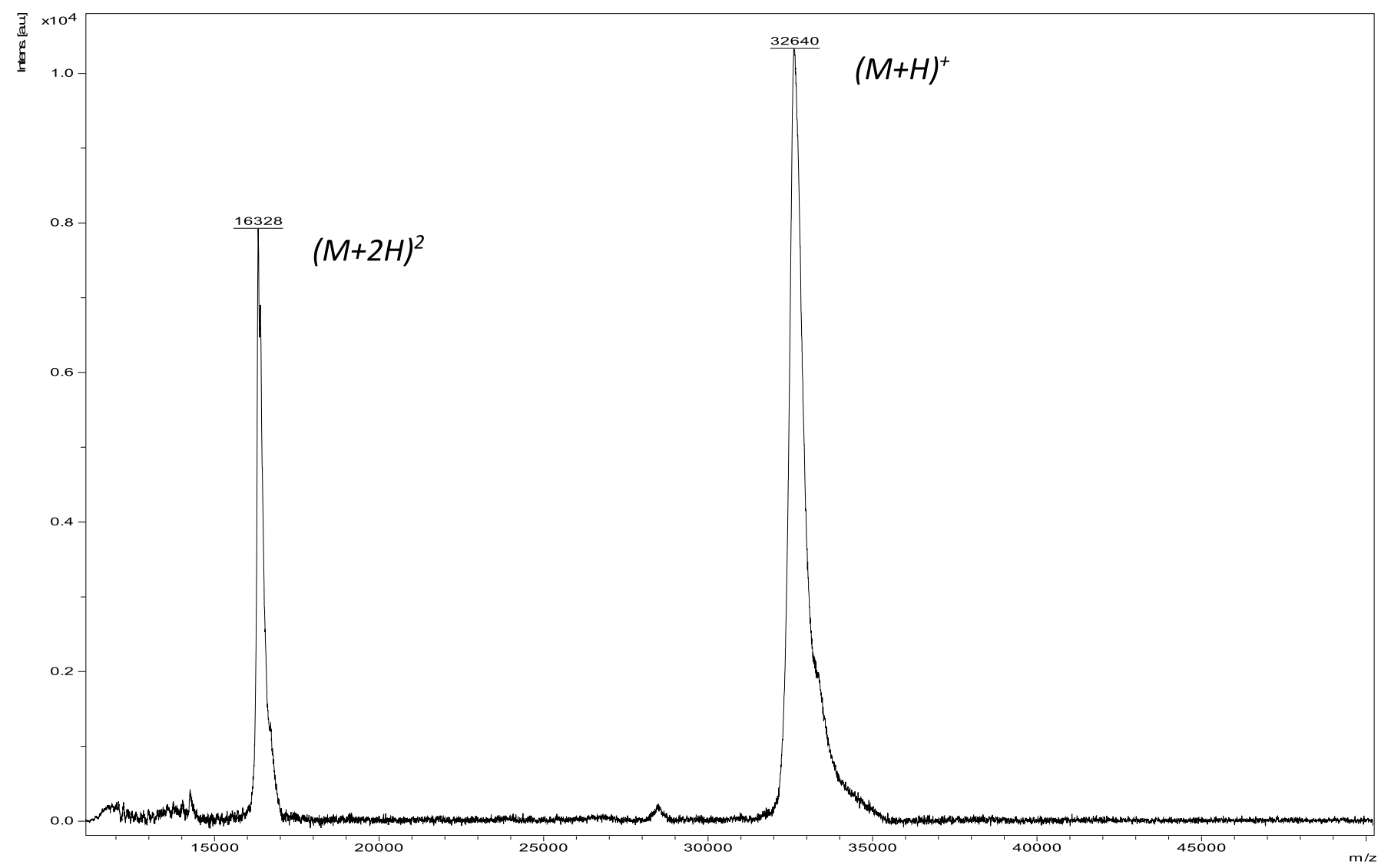

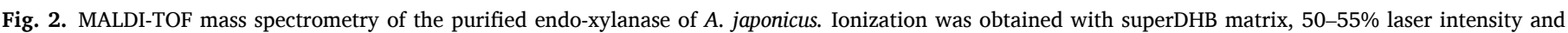

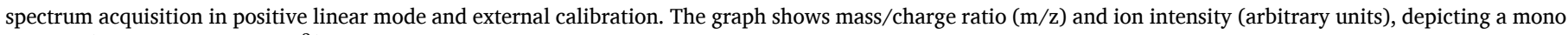
$(\mathrm{M} H)$ and double $(\mathrm{M} 2 \mathrm{H})^{2}$ charged main component of 32,639 Da.

overall costs of biocatalysis reaction processes. The xylanase from Aspergillus niger BCC 14405, using ion exchange and hydrophobic chromatography, showed a 5 -fold purification and $20.7 \%$ recovery (Krisana et al., 2005). Another A. niger xylanase purification using ion exchange and gel permeation chromatography showed a 36.97-fold purification with $38.9 \%$ recovery ( $\mathrm{Pal}$ and Khanum, 2011). The apparent molecular mass of the purified endo-xylanase was $32 \mathrm{kDa}$, as estimated by SDS-PAGE (Fig. 1). This result was confirmed by MALDI-TOF mass spectrometry analysis, with a main component of $32.6 \mathrm{kDa}$ (Fig. 2). The molecular mass of the purified endo-xylanase of A. japonicus was similar to the xylanases from Aspergillus caespitosus (Sandrim et al., 2005), Aspergillus versicolor (Carmona et al., 2005), Aspergillus awamori (Teixeira et al., 2010) and A. niger DFR-5 (Pal and Khanum, 2011). Kulkarni et al. (1999) reported that microbial xylanases are single subunit proteins within a range of $8-145 \mathrm{kDa}$.

To verify the identity of the purified endo-xylanase, a peptide mass fingerprint was obtained after acrylamide band excision and in-gel trypsin digestion of the electrophoresed protein (Fig. 3). A survey in the protein sequence data banks using the MASCOT algorithm revealed significant identity with two sequences, both Aspergillus aculeatus endoxylanases belonging to family 10 of glycoside hydrolases (GH). The UniProtKB/Swiss-Prot sequence deposited with access O59859.1 (score $121 ; \mathrm{p}<0.001$ ) had $71 \%$ coverage, while for the GenBank access ALI87002.1 (score 99; $\mathrm{p}<0.02$ ) the coverage was $60 \%$, suggesting that the similarity level of our enzyme with the A. aculeatus sequences is very high. Further analysis by top-down fragmentation rendered an amino-terminal sequence of 21 residues, which presented $84 \%$ similarity with $A$. japonicus var. aculeatus xylanases (not shown), strengthening the relatedness of our enzyme with the xylanase family.

The sequenced DNA of cluster region ITS1-5.8S-ITS4 was analysed using Geneious Software (Geneious Prime ${ }^{\circledR}$ 2019.0.4) (Kearse et al., 2012). These results were compared with GenBank database sequences (Benson et al., 2005) to identify the fungus homology and identity (http: //www.ncbi.nlm.nih.gov/BLAST/). The genomic analysis showed 100\% identity with A. japonicus var. aculeatus in BLAST under accession number MH567078. Filamentous fungi can exhibit a multiplicity of xylanases, in some cases three or more endo-xylanases have been separated from a single culture, which may differ by post-translational modifications and processing, probably due to an adaptive response of these microorganisms to optimize their biodegradation mechanisms (Rizzatti et al., 2004; Paes et al., 2012). However, genes involved in xylanase production can reflect phylogenetic relationships of closely related taxa (Degefu et al., 2004).

\subsection{Biochemical characterization of the endo-xylanase}

The $\mathrm{pH}$ effect on the purified endo-xylanase activity is shown in Fig. 4a. The optimal endo-xylanase activity was at a range of $\mathrm{pH}$ from 5.0 to 6.0. The majority of purified fungal xylanases that have been reported are optimally active at the acidic $\mathrm{pH}$ range from 4.5 to 6.5 (Polizeli et al., 2005; Hmida-Sayari et al., 2012; Silva et al., 2015b; Sharma, 2017), and few neutral or alkaliphilic xylanases are reported in mesophilic fungus species of the Aspergillus genus (Polizeli et al., 2005). The pH stability was determined by verifying the remaining activity after incubating the purified enzyme for $24 \mathrm{~h}$ at room temperature. In Fig. $4 \mathrm{~b}$, it can be seen that $\mathrm{pH}$ stability for purified endo-xylanase at all $\mathrm{pH}$ studied was over $70 \%$ for $24 \mathrm{~h}$. A xylanase isolated from Aspergillus nidulans has been found to be stable at $\mathrm{pH} 3.5-10.0$ after $4 \mathrm{~h}$ of incubation (Reis et al., 2003; Juturu and Wu, 2012). Acidic xylanases can be very useful in the clarification of fruit juices and wines. Microbial xylanases from 


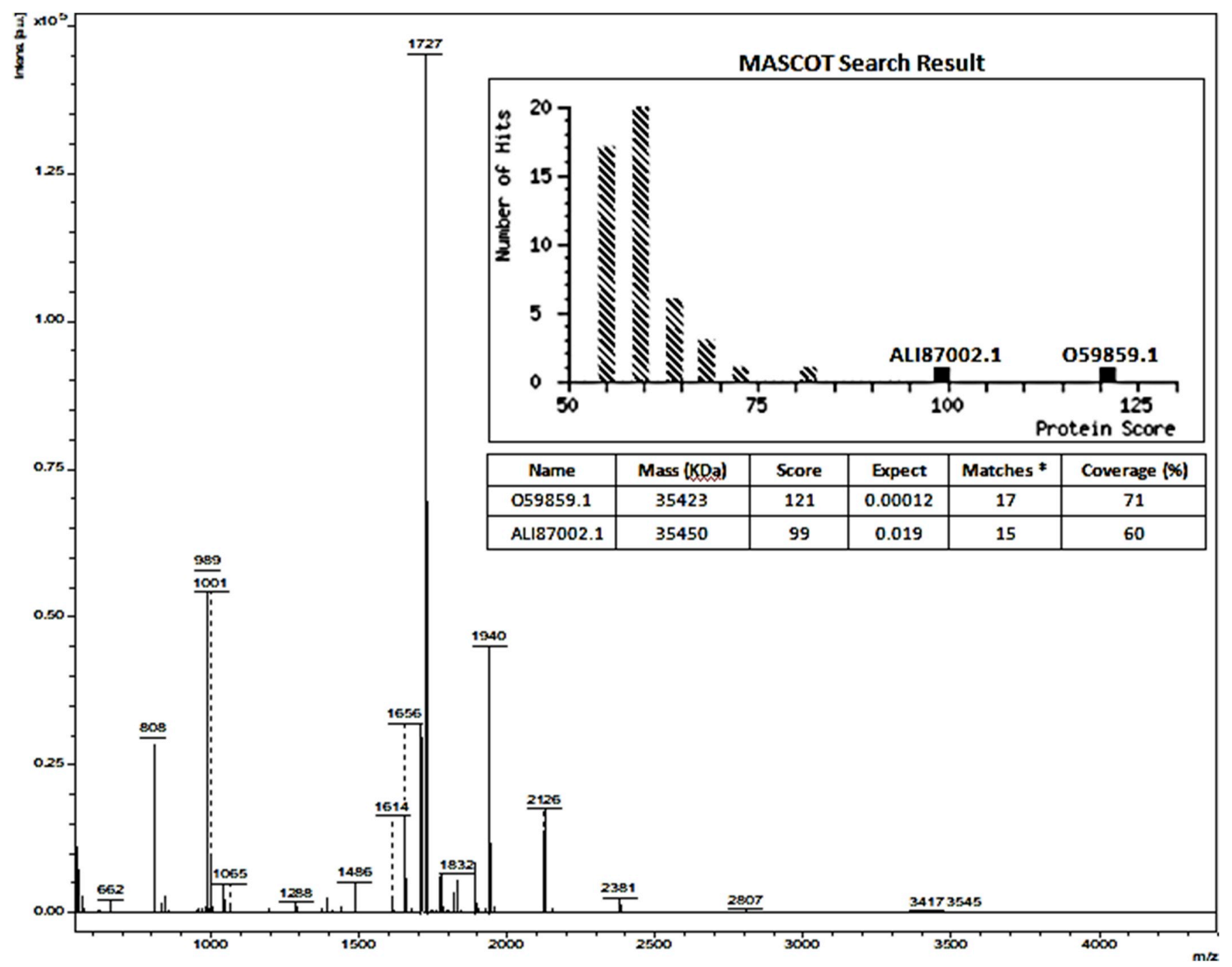

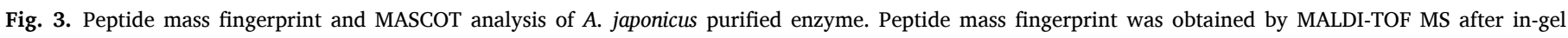

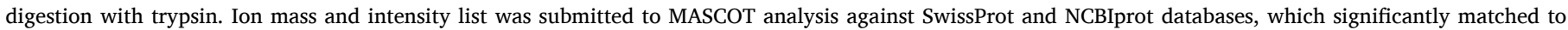

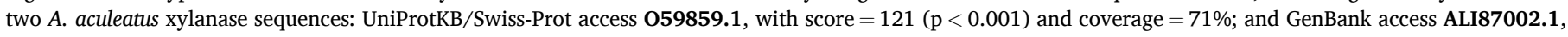
with score $99(\mathrm{p}<0.02)$ and coverage $\quad 60 \%$. * number of matched peptides out of 42 from A. japonicus xylanase peptide mass list.

mesophilic and thermophilic fungi and bacteria species are usually stable over a broad pH range (3.0-10.0) (Polizeli et al., 2005; Sharma, 2017; Walia et al., 2017). Moreover, the xylanases that are stable over a wide $\mathrm{pH}$ range could be very suitable for applications in the feed industry (Knob and Carmona, 2010; Juturu and Wu, 2012).

The optimal A. japonicus endo-xylanase activity occurred from 50 to $60 \mathrm{C}$, decreasing only $7.4 \%$ and $1.5 \%$ (respectively), when compared to the maximum endo-xylanase activity at $55 \mathrm{C}$. The enzyme also retained its activity of approximately $50 \%$ at $65 \mathrm{C}$ and $25 \%$ from $70 \mathrm{C}$ to $80 \mathrm{C}$ (Fig. 5a). The optimal temperature for purified $A$. japonicus endoxylanase activity was similar to other xylanases of Aspergillus species and other xylanase-producing microorganisms (mesophiles and thermophiles), which ranged from 25 to 80 C (Polizeli et al., 2005; Chakdar et al., 2016; Sharma, 2017). The effect of temperature on purified endo-xylanase stability was determined by measuring the relative activity after intervals from 10 to $240 \mathrm{~min}$ of incubation the enzyme in McIlvaine buffer pH 5.0 (in the absence of substrate) at 40, 45, 50 and $55 \mathrm{C}$ (Fig. 5b). The enzyme was stable at 40 and $45 \mathrm{C}$ and retained $50 \%$ of its activity after $240 \mathrm{~min}\left(\mathrm{t}_{1 / 2}\right)$ of incubation at 50 and $55 \mathrm{C}$. Other mesophilic and thermophilic fungi, including various Aspergillus species, exhibit a broad xylanase thermostability range from 35 to $100 \mathrm{C}$
(Ahmed et al., 2009; Michelin et al., 2010; Peng et al., 2012).

It is known that xylanases may have their hydrolytic activity modulated by metal ions, organic solvents and detergents. Most xylanases are found to be inhibited by $\mathrm{Mn}^{2}$ (Saha, 2002). However, A. japonicus endo-xylanase was stimulated by $\mathrm{Mn}^{2}$ at 1 and $5 \mathrm{mM}$, corresponding to $34.5 \%$ and $22.7 \%$, respectively (Table 2). Silva et al. (2015b) reported similar results for xylanase (xyl I) from T. inhamatum using $10 \mathrm{mM}$ divalent ions $\left(\mathrm{Mn}^{2}, \mathrm{Mg}^{2}, \mathrm{Co}^{2}\right.$ and $\mathrm{Ca}^{2}$ ). However, strong inhibition of xylanolytic relative activity was observed for A. ficuum A-98 (Lu et al., 2008), A. niger US368 (Hmida-Sayari et al., 2012) and A. terreus (Vitcosque et al., 2016) in the presence of these ions. Juturu and $\mathrm{Wu}(2012)$ reported that the presence of the $\mathrm{Ca}^{2}$ binding site plays a role in preventing the thermal inactivation, unfolding and proteolysis of hemicellulases. Other metal ions that were tested had minor influences on the endo-xylanolytic activity of A. japonicus. On the other hand, purified enzymes from the mesophilic fungi A. ficuum, A. terreus and T. inhamatum presented a range of effects, from small to substantial inhibition of xylanase activity (Lu et al., 2008; Hmida-Sayari et al., 2012; Silva et al., 2015b; Vitcosque et al., 2016).

A. japonicus endo-xylanase was activated by 0.01 and $0.1 \mathrm{M} \beta$-mercaptoethanol $(40.52 \%$ and $29.85 \%$, respectively), Triton $\mathrm{X}-100$ 


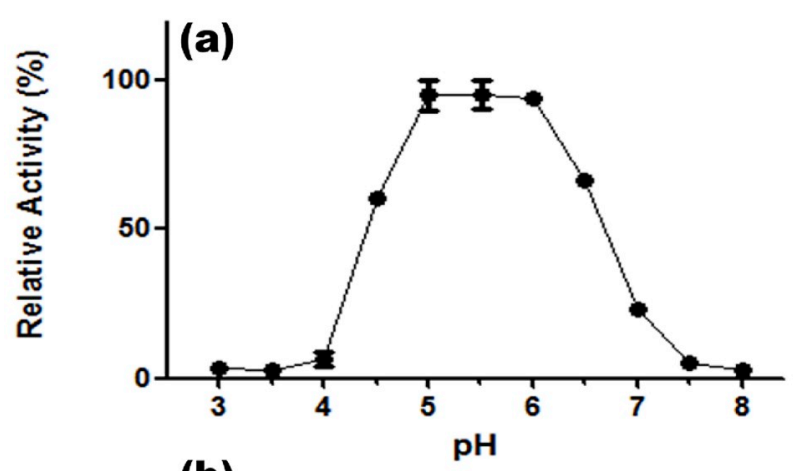

(b)

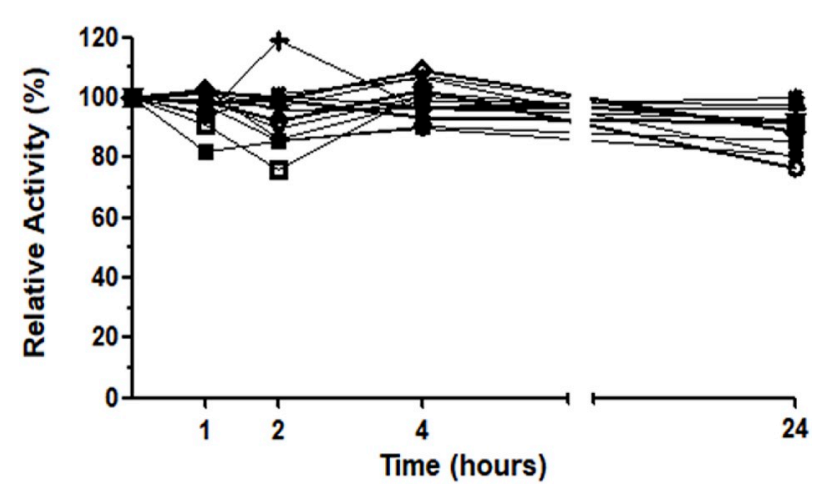

Fig. 4. Influence of $\mathrm{pH}$ on the activity and stability of $A$. japonicus endoxylanase. Assay conditions: (a) $1 \%(\mathrm{w} / \mathrm{v}$ ) birchwood xylan in $\mathrm{pH} 3.0-8.0$ McIlvaine buffer, $50 \mathrm{C}$; (b) the enzymatic preparations were incubated in $\mathrm{pH}$ $3.0(\square) ; 3.5(\square) ; 4.0(\circ) ; 4.5(\bullet) ; 5.0\left(\right.$ ); $5.5(\diamond) ; 6.0(\diamond) ; 6.5(\Delta)$ ); $7.0\left({ }^{(}\right) ; 7.5$ $(\boldsymbol{\nabla})$ and $8.0(\mathbf{\Lambda})$, without substrate. All experiments were performed in triplicate.

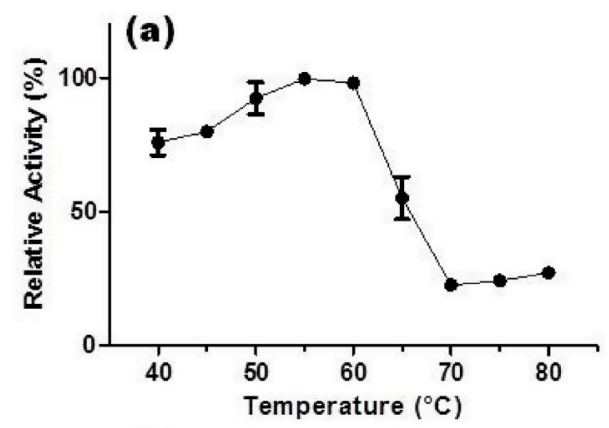

(b)

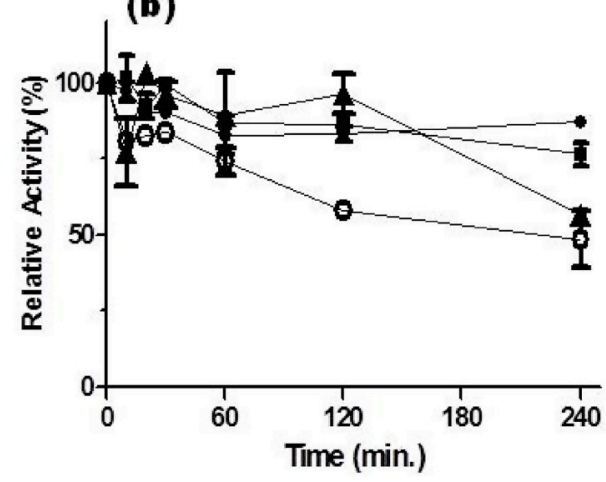

Fig. 5. Influence of temperature on the activity and stability of A. japonicus endo-xylanase. Assay conditions: (a) $1 \%(\mathrm{w} / \mathrm{v}$ ) birchwood xylan in McIlvaine buffer $\mathrm{pH} 5.0$ at temperatures ranging from 40 to $80 \mathrm{C}$; (b) enzymatic preparation aliquots were incubated at $40 \mathrm{C}(\boldsymbol{\bullet}) ; 45 \mathrm{C}(\boldsymbol{\square}) ; 50 \mathrm{C}(\mathbf{\Delta})$ and $55 \mathrm{C}(\mathrm{o})$. All experiments were performed in triplicate.
Table 2

Effect of metal ions ( 1 and $5 \mathrm{mM}$ ) and Ethylenediaminetetraacetic acid (EDTA) on the activity of $A$. japonicus endo-xylanase.

\begin{tabular}{llllll}
\hline \multirow{2}{*}{ Ions } & \multicolumn{4}{l}{ Relative activity (\%) } \\
\cline { 2 - 6 } & $1 \mathrm{mM}$ & \multicolumn{3}{l}{$5 \mathrm{mM}$} \\
\hline $\mathrm{Control}$ & 100,0 & 0,01 & 100,0 & 0,06 \\
$\mathrm{NH}_{4} \mathrm{Cl}$ & 106,0 & 4,92 & 90,8 & 1,15 \\
$\mathrm{CuSO}$ & 92,3 & 2,09 & 43,1 & 4.23 \\
$\mathrm{MgSO}_{4}$ & 104,2 & 0,11 & 77,3 & 7,19 \\
$\mathrm{FSO}_{4}$ & 99,6 & 3,45 & 81,8 & 7,03 \\
$\mathrm{KCl}_{\mathrm{CaCl}}$ & 99,8 & 5,12 & 83,0 & 1,93 \\
$\mathrm{CoCl}_{2}$ & 103,0 & 3,86 & 83,3 & 1,73 \\
$\mathrm{EDTA}$ & 105,6 & 0,52 & 70,0 & 7,78 \\
$\mathrm{ZnCl}_{2}$ & 108,0 & 0,19 & 66,1 & 3,88 \\
$\mathrm{MnCl}_{2}$ & 116,3 & 1,36 & 86,8 & 1,08 \\
$\mathrm{BaCl}_{2}$ & 134,5 & 0,41 & 122,7 & 3,28 \\
\hline
\end{tabular}

Control: without addition of ions.

Table 3

Effect of various substances on endo-xylanase activity from $A$. japonicus.

\begin{tabular}{|c|c|c|c|c|}
\hline $\begin{array}{l}\text { Phenolic } \\
\text { compounds (1mg/ } \\
\mathrm{mL})\end{array}$ & $\begin{array}{l}\text { Detergent } \\
(10 \%)\end{array}$ & $\begin{array}{l}\text { Organic } \\
\text { solvent (10 } \\
\%)\end{array}$ & $\begin{array}{l}\text { Reducing } \\
\text { agents }\end{array}$ & $\begin{array}{l}\text { Residual } \\
\text { activity (\%) }\end{array}$ \\
\hline $\begin{array}{l}\text { Control } \\
\text { Vanillin }\end{array}$ & \multirow[t]{6}{*}{ Control } & \multirow[t]{11}{*}{ Control } & \multirow[t]{5}{*}{ Control } & $\begin{array}{l}100 \quad 0.14 \\
78.25 \\
2.09\end{array}$ \\
\hline Ferulic acid & & & & $\begin{array}{l}117.26 \\
2.66\end{array}$ \\
\hline Cinnamic acid & & & & $\begin{array}{l}70.45 \\
0.35\end{array}$ \\
\hline $\begin{array}{l}\text { 4-hydroxybenzoic } \\
\text { acid }\end{array}$ & & & & $\begin{array}{l}84.40 \\
0.43\end{array}$ \\
\hline Coumaric acid & & & & $\begin{array}{l}86.29 \\
0.57\end{array}$ \\
\hline \multirow[t]{13}{*}{ Tannic acid } & & & $\begin{array}{l}2-\mathrm{ME} \\
(0.01 \mathrm{M}) \\
2-\mathrm{ME} \\
(0.1 \mathrm{M})\end{array}$ & $\begin{array}{l}8.75 \quad 0.98 \\
140.52 \\
0.35 \\
129.85 \\
0.99\end{array}$ \\
\hline & Triton X- & & & 201.61 \\
\hline & 100 & & & 0.05 \\
\hline & Tween- 20 & & & $\begin{array}{l}191.94 \\
0.03\end{array}$ \\
\hline & Tween- 80 & & & $\begin{array}{l}138.87 \\
0.13\end{array}$ \\
\hline & SDS & & & $\begin{array}{ll}0 & 0.05\end{array}$ \\
\hline & & Acetonitrile & & $\begin{array}{l}72.10 \\
0.06\end{array}$ \\
\hline & & Butanol & & $\begin{array}{l}53.75 \\
0.04\end{array}$ \\
\hline & & Acetone & & $\begin{array}{l}78.28 \\
0.06\end{array}$ \\
\hline & & Isopropanol & & $\begin{array}{l}68.91 \\
0.05\end{array}$ \\
\hline & & Methanol & & $\begin{array}{l}54.87 \\
0.05\end{array}$ \\
\hline & & DMSO & & $\begin{array}{l}68.16 \\
0.12\end{array}$ \\
\hline & & Ethanol & & $\begin{array}{l}59.36 \\
0.03\end{array}$ \\
\hline
\end{tabular}

ME 2-mercaptoethanol (0.1M).

(101.61\%), Tween-20 (91.94\%) and Tween-80 (38.97\%). Considering that both Tween and Triton are nonionic surfactants, these would promote proteins disaggregation improving enzymatic hydrolysis by exposure of their catalytic sites (Monclaro et al., 2016) (Table 3). On the other hand, the enzyme was inactivated by SDS, indicating the importance of hydrophobic interactions for the maintenance of its three-dimensional structure since SDS is an anionic detergent and a strong denaturant of proteins (Manning and Colon, 2004). These results 
Table 4

Kinetic parameters of xylanases produced by filamentous fungi.

\begin{tabular}{|c|c|c|c|c|c|}
\hline Strain & $\begin{array}{l}\text { Vmax } \\
(\mu \mathrm{mol} / \\
\min / \mathrm{mg})\end{array}$ & $\begin{array}{l}\mathrm{Km} \\
(\mathrm{mg} / \\
\mathrm{mL})\end{array}$ & $\begin{array}{l}\text { Kcat } \\
\left(s^{1}\right)\end{array}$ & $\begin{array}{l}\text { Kcat/ } \\
\text { Km (mL } \\
\mathrm{s}^{1} \\
\left.\mathrm{mg}^{1}\right)\end{array}$ & References \\
\hline A. japonicus & 467.4 & 2.59 & 253.95 & 98.05 & (Present study) \\
\hline A. ficuum & 11.1 & 3.74 & - & - & $\begin{array}{l}\text { Fengxia et al. } \\
\text { (2008) }\end{array}$ \\
\hline A. awamori & 10000.0 & 1.0 & - & - & $\begin{array}{l}\text { Subramaniyan } \\
\text { and Prema } \\
\text { (2002) }\end{array}$ \\
\hline A. awamori & 333.0 & 0.33 & - & - & $\begin{array}{l}\text { Subramaniyan } \\
\text { and Prema } \\
\text { (2002) }\end{array}$ \\
\hline A. awamori & 455.0 & 0.09 & - & - & $\begin{array}{l}\text { Subramaniyan } \\
\text { and Prema } \\
(2002)\end{array}$ \\
\hline A. nidulans & 1091.0 & 0.97 & - & - & $\begin{array}{l}\text { Subramaniyan } \\
\text { and Prema } \\
\text { (2002) }\end{array}$ \\
\hline A. terreus & 17.4 & 1.20 & 1.6 & 1.3 & $\begin{array}{l}\text { Vitcosque et al. } \\
\text { (2016) }\end{array}$ \\
\hline A. niger & 811.0 & 1.03 & 472.9 & 459.2 & $\begin{array}{l}\text { Hmida-Sayari } \\
\text { et al. (2012) }\end{array}$ \\
\hline C. graminicola & 481.3 & 3.7 & 136.4 & 36.9 & $\begin{array}{l}\text { Carli et al. } \\
\text { (2016) }\end{array}$ \\
\hline $\begin{array}{l}\text { M. flava (MFX } \\
\text { I) }\end{array}$ & 3333.0 & 6.6 & 700.2 & 106.1 & $\begin{array}{l}\text { Sharma et al. } \\
\text { (2010) }\end{array}$ \\
\hline $\begin{array}{l}\text { M. flava (MFX } \\
\text { II) }\end{array}$ & 1923.0 & 5.0 & 357.5 & 71.5 & $\begin{array}{l}\text { Sharma et al. } \\
\text { (2010) }\end{array}$ \\
\hline P. thermophila & 1424.7 & 1.6 & 612.6 & 382.9 & Li et al. (2006) \\
\hline $\begin{array}{r}\text { T. lanuginosus } \\
\text { CBS } 288.54\end{array}$ & 2402.3 & 4.0 & 1049 & 262.3 & Li et al. (2005) \\
\hline
\end{tabular}

are similar to those described for A. niger US368 (Hmida-Sayari et al., 2012), T. inhamatum (Silva et al., 2015b) and A. terreus (Vitcosque et al., 2016). A strong inhibition by SDS was also observed for Penicillium sclerotiorum xylanase (Knob and Carmona, 2010). The A. japonicus endo-xylanase was also inhibited by organic solvents and phenolic compounds, except ferulic acid, which is a plant cell wall-bound component and a precursor in lignocellulosic biomass; it has been suggested that it plays key roles in cell defence and cell wall development (Wallace and Fry, 1999). Studies have demonstrated that the inhibitory effects of phenolic compounds are due to conformational changes that induce protein steric inactivation (Boukari et al., 2011). A similar result was found by Monclaro et al. (2016) in which Aspergillus tamarii xylanase activity increased with the addition of ferulic acid. According to Monclaro et al. (2019), the inhibitory effect of phenolic compounds on the cellulases and hemicellulases activities has been described. But interestingly, in the present study, the endo-xylanase activity from A. japonicus was stimulated by ferulic acid. A comparative study about the hydrolysis of different types of xylans in the presence of phenolic compounds showed that the xylanase activity from A. tamarii (AtXyl1) was also increased in the presence of vanillin and tannic acid using birchwood xylan. Moreover, the hydrolysis of beechwood xylan by AtXyl1 was stimulated by these phenolic acids above and also by p-coumaric, cinnamic, ferulic and 4-hydroxybenzoic acids (Monclaro et al., 2019). Although the mechanism of modulation of enzyme activity by phenolic acids still remains to be clarified, Monclaro et al. (2019), using molecular docking of three-dimensional structure of GH11 xylanase from A. niger model, in the presence or absence of xylooligosaccharides, launched a better understand about the interactions between phenolic acids and the GH11 xylanases. In this simulation, the Tyr164, Ser 94 and Tyr89 residues in catalytic domain can be involved in these interactions with phenolic acids. Other studies also corroborate the role of these amino acids in phenolic acids interactions with xylan hydrolysis by GH11 xylanases (Krengel and Djikstra, 1996; Vandermarliere et al., 2008; Tison et al., 2009; Paes et al., 2012).

The A. japonicus purified endo-xylanase was also assayed for

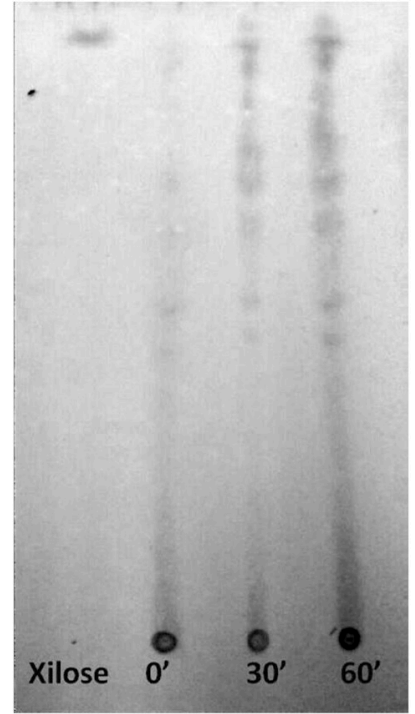

Fig. 6. Thin-layer chromatography (TLC) of hydrolysis products using $1 \%$ (w/ v) birchwood xylan substrate upon reaction with endo-xylanase from A. japonicus. Lane 1: xylose $5 \mathrm{mg} / \mathrm{mL}$; Lanes $2-4$ : hydrolysis products using xylanase after 0,30 and $60 \mathrm{~min}$ of incubation, respectively.

hydrolytic activity against a variety of substrates. As previously described (Silva et al., 2015a; Vitcosque et al., 2016) the A. japonicus purified endo-xylanase showed a high specificity for birchwood xylan and did not act towards avicel, starch or carboxymethylcellulose (not shown), indicating the specific breakdown of $\beta$-anomeric glycosidic linkages of xylose residues, as demonstrated by Carli et al. (2016). The A. japonicus endo-xylanolytic activity showed a single stimulation curve in the presence of different birchwood xylan concentrations (ranging from 0.02 to $0.5 \%, \mathrm{w} / \mathrm{v}$ ). The endo-xylanase maximal velocity (Vmax) was $467.430 .38 \mu \mathrm{mol} / \mathrm{min} / \mathrm{mg}$, with a $\mathrm{km}$ value of $2.590 .17 \mathrm{mg} / \mathrm{mL}$, a kcat value of $253.9516 .51 \mathrm{~s}^{1}$ and a kcat $/ \mathrm{km}$ value of $98.054 .41 \mathrm{~mL} \mathrm{~s}^{1} \mathrm{mg}{ }^{1}$. Kinetic studies of other fungi producers of xylanases are presented in Table 4.

The resulting products from the hydrolysis of birchwood xylan by the purified endo-xylanase were analysed by TLC (Fig. 6). The hydrolysis products obtained from $A$. japonicus purified xylanase consisted of xylooligosaccharides of various lengths and xylose. It is known that endo-xylanases randomly cleave $\beta$-1,4-glycosidic linkages inside the xylan main chain and release xylooligosaccharides of different lengths, while $\beta$-xylosidases release xylose from xylobiose and xylooligosaccharides (Zimbardi et al., 2013). Since xylooligosaccharides were released by xylan hydrolysis, the A. japonicus purified enzyme was classified as an endo-xylanase, corroborating the similarity of the endo-xylanases found in the MASCOT analysis. The production of xylooligosaccharides as product has also been observed by TLC using endo-xylanases from Aspergillus flavus (Chen et al., 2019), Neosartorya tatenoi (Seemakram et al., 2016), Thermoascus aurantiacus (Chanwicha et al., 2015), A. terreus (Sorgatto et al., 2012) and Aspergillus carneus (Fang et al., 2008) from birchwood xylan; and Trichoderma inhamatum (Silva et al., 2015b) from oat spelt xylan. Aspergillus oryzae LC1 produced xylooligosaccharides (xylobiose, xylotriose and xylotetraose) by the enzymatic hydrolysis of sugar cane bagasse, wheat straw and wheat bran from lignocellulosic biomass (Bhardwaj et al., 2019).

\subsection{Fruit juice clarification and hydrolysis of fruit peel wastes by endo-} xylanase from A. japonicus

Carbohydrate polymers such as pectin, starch and hemicellulosic components present in fruit juices make them cloudy and viscous. These cloudy juices are less attractive to consumers and also make them 
Table 5

Fruit juice clarification and hydrolysis of fruit peel wastes by endo-xylanase of A. japonicus.

\begin{tabular}{|c|c|c|c|c|c|}
\hline \multirow{2}{*}{$\begin{array}{l}\text { Fruits (in } \\
\text { nature) }\end{array}$} & \multicolumn{2}{|c|}{$\begin{array}{l}\text { Reducing sugars yield in fruit } \\
\text { peel waste hydrolysis by endo- } \\
\text { xylanase ( } \mu \mathrm{mol})\end{array}$} & \multicolumn{2}{|c|}{$\begin{array}{l}\text { Fruit juice } \\
\text { clarification (\% } \\
\text { Clarification) }\end{array}$} & \multirow{2}{*}{$\begin{array}{l}\text { Fruit } \\
\text { juice } \mathrm{pH} \\
3.5-4.0\end{array}$} \\
\hline & 2.89 & 1.63 & 6.11 & 0.10 & \\
\hline Banana & 3.36 & 1.05 & 9.99 & 1.34 & $4.0-4.5$ \\
\hline Orange & 1.85 & 0.10 & 2.66 & 0.09 & $4.0-4.5$ \\
\hline Mango & 2.69 & 0.08 & 51.11 & 0.08 & $4.0-4.5$ \\
\hline Tangerine & 1.91 & 0.09 & 8.54 & 0.08 & $4.0-4.5$ \\
\hline Nectarine & 1.00 & 0.05 & ND & & $4.0-4.5$ \\
\hline Peach & 0.66 & 0.09 & ND & & $4.0-4.5$ \\
\hline Ponkan & 2.16 & 0.03 & 1.39 & 0.08 & $4.0-4.5$ \\
\hline
\end{tabular}

ND not detectable.

difficult to pasteurize and concentrate. Progressive degradation of the middle lamella between the cells can be done by hydrolytic enzymes, weakening the wall and resulting in the release of cell bound materials including water, thus making the juice recovery easier. When fruit juices are treated with xylanases, reducing carbohydrate units are released, allowing for better pulp processing and improvement of the yield of the substances contained in the fruit. Thus, the amount of reducing sugars released is the indicator for the breakdown of hemicellulose materials by the enzyme, being the calculation in transmittance percentage a measure of the clarity of the juice (Rosmine et al., 2017). The A. japonicus endo-xylanase activity in the clarification of fruit juices and in the hydrolysis of fruit peel wastes are illustrated in Table 5. Enzyme-treated juice gave a $51.11 \%, 9.99 \%$ and $8.54 \%$ increase in the clarity of mango, banana and tangerine juices, respectively. Bacterial xylanases used in juice clarification processes have been described in the literature with Pediococcus acidilactici GC25 (Adiguzel et al., 2019), Bacillus licheniformis (Bajaj and Manhas, 2012) and Bacillus stearothermophilus (Dhiman et al., 2011). However, there are few reports on fungal xylanases in fruit juice clarification processes, mainly using only purified xylanases. Usually, pectinases are used in these processes or along with xylanases, cellulases and amylases (Padma et al., 2017; Sharma, 2017; Dhiman et al., 2011). The xylanase produced by Streptomyces sp. showed increases in the clarity of orange, mousambi and pineapple juices by $20.87 \%, 23.64 \%$ and $27.89 \%$, respectively (Rosmine et al., 2017). A study using hot water extraction with a combination of pectinases and cellulases in apple pomace resulted in a $37 \%$ increase in juice yield (Will et al., 2000). An approximately $25 \%$ increase in pineapple juice recovery was obtained when a mixture of two commercial enzymes, pectinase and hemicellulase, were used at $40 \mathrm{C}$ compared to the control in studies of Tochi et al. (2009). In the current study, endo-xylanase $(0.42 \mathrm{mg} / \mathrm{mL}$ protein) was incubated for $15 \mathrm{~min}$ at $55 \mathrm{C}$ and showed activity toward all fruit peels. The liberation of reducing sugar towards theses fruit peel wastes was higher at banana peel $(3.36 \mu \mathrm{mol})$ and pineapple peel $(2.85 \mu \mathrm{mol})$, decreasing to mango $(2.69 \mu \mathrm{mol})$ and ponkan $(2.16 \mu \mathrm{mol})$ peels. Xylanase showed efficiency for releasing reducing sugars from fruit peel wastes, showing potential to be used in an alternative route for fruit waste use in the economical and sustainable production of biofuel. In addition, the hydrolysis of the fruit peel wastes by the endo-xylanase liberating reducing sugars from their hemicellulose components is important as it can be used to improve the nutritional properties of feed and reduce environmental pollution.

\section{Conclusion}

The present study features a promising approach for the production of $A$. japonicus endo-xylanase in liquid cultures with wheat bran, and the use of this enzyme in biotechnological processes. Furthermore, the purification was carried out through a single chromatography step, which reduces the cost and time for obtaining the pure enzyme. The peptide mass fingerprint MASCOT results, together with the amino-terminal sequence of our A. japonicus-purified enzyme, strongly suggest its identity as a new member of the xylanase family. Other pivotal properties such as its high efficiency in juice clarification and in the saccharification of peel wastes from the fruit juice industry indicate this enzyme as a promising and excellent candidate for applications in biotechnological processes.

\section{Conflicts of interest}

The authors declare that they have no conflict of interest.

\section{Acknowledgements}

This work was supported by grants from Conselho de Desenvolvimento Científico e Tecnologico (CNPq). This work was part of Master Dissertation of Silva, PO (Laboratorio de Bioquímica e de Microrganismos/Universidade Federal de Mato Grosso do Sul, Campo Grande, MS, Brazil).

\section{References}

Adiguzel, G., Faiz, O., Sisecioglu, M., Sari, B., Baltaci, O., Akbulut, S., Genc, B., Adiguzel, A., 2019. A novel endo- $\beta-1,4$-xylanase from Pediococcus acidilactici GC25; purification, characterization and application in clarification of fruit juices. Int. J. Biol. Macromol. 15 (129), 571-578. https://doi.org/10.1016/j. ijbiomac.2019.02.054.

Ahmed, S., Riaz, S., Jamil, A., 2009. Molecular cloning of fungal xylanases: an overview. Appl. Microbiol. Biotechnol. 84, 19-35.

Amita, R.S., Shah, R.K., Madamwar, D., 2006. Improvement of the quality of whole wheat bread by supplementation of xylanase from Aspergillus foetidus. Bioresour. Technol. 97, 2047-2053.

Bajaj, B.K., Manhas, K., 2012. Production and characterization of xylanase from Bacillus lichenoformis PH (C) with potential for fruit juice and bakery industry. Biocatal. Agric. Biotechnol. 1, 330-337.

Bhardwaj, N., Kumar, B., Agarwal, K., Chaturvedi, V., Verma, P., 2019. Purification and characterization of a thermo-acid/alkali stable xylanases from Aspergillus oryzae LC1 and its application in Xylo-oligosaccharides production from lignocellulosic agricultural wastes. Int. J. Biol. Macromol. 1 (122), 1191-1202.

Benson, D.A., Karsch-Mizrachi, I., Lipman, D.J., Ostell, J., Wheeler, D.L., 2005. GenBank. Nucleic Acids Res. 33, D34-D38.

Boukari, I., O'Donohue, M., Remond, C., Chabbert, B., 2011. Probing a family GH11 endo- $\beta-1,4$-xylanase inhibition mechanism by phenolic compounds: role of functional phenolic groups. J. Mol. Catal. B Enzym. 72, 130-138.

Carli, S., Meleiro, L.P., Rosa, J.C., Moraes, L.A.B., Jorge, J.A., Masui, D.C., Furriel, R.P. M., 2016. A novel thermostable and halotolerant xylanase from Colletotrichum graminicola. J. Mol. Catal. B Enzym. 133, S508-S517.

Carmona, E.C., Fialho, M.B., Buchgnani, E.B., Coelho, G.D., Brocheto-Braga, M.R., Jorge, J.A., 2005. Production, purification and characterization of a minor form of xylanase from Aspergillus versicolor. Process Biochem. 40, 359-364.

Chakdar, H., Kumar, M., Pandiyan, K., Singh, A., Nanjappan, K., Kashyap, P.L., Srivastava, A.K., 2016. Bacterial xylanases: biology to biotechnology. Biotech 6, 150.

Chanwicha, N., Katekaew, S., Aimi, T., Boonlue, S., 2015. Purification and characterization of alkaline xylanase from Thermoascus aurantiacus var. levisporus KKU-PN-I2-1 cultivated by solid-state fermentation. Mcoscience 56, 30-318.

Chen, Z., Zaky, A.A., Liu, Y., Chen, Y., Liu, L., Li, S., Jia, Y., 2019. Purification and characterization of a new xylanase with excellent stability from Aspergillus flavus and its application in hydrolyzing pretreated corncobs. Protein Expr. Purif. 154, 91-97.

De Alencar Guimarães, N.C., Sorgatto, M., Peixoto-Nogueira, S.C., Betini, J.H.A., Zanoelo, F.F., Marques, M.R., Polizeli, M.L.T.M., Giannesi, G.C., 2013. Bioprocess and biotechnology: effect of xylanase from Aspergillus niger and Aspergillus flavus on pulp biobleaching and enzyme production using agroindustrial residues as substract. SpringerPlus 2, 380.

Degefu, Y., Lohtander, K., Paulin, L., 2004. Expression patterns and phylogenetic analysis of two xylanase genes (htxyl1 and htxyl2) from Helminthosporium turcicum, the cause of northern leaf blight of maize. Biochimie 86, 83-90.

Dhiman, S.S., Garg, G., Sharma, J., Mahajan, R., Methoxy, 2011. Characterization of statistically produced xylanase for enrichment of fruit juice clarification process. N. Biotech. 28 (6), 746-755.

Druzhinina, I.S., Kopchinskiy, A.G., Komoj, M., Bisset, J., Szakacs, G., Kubicek, C.P. 2005. An oligonucleotide barcode for species identification in Trichoderma and Hypocrea. Fungal Genet. Biol. 42, 813-828.

Fang, H.Y., Chang, S.M., Lan, C.H., Fang, T.J., 2008. Purification and characterization of a xylanase from Aspergillus carneus M34 and its potential use in photoprotectant preparation. Process Biochem. 43 (1), 49-55.

Fengxia, L., Mei, L., Zhaoxin, L., Xiaomei, B., Haizhen, Z., Yi, W., 2008. Purification and characterization of xylanase from Aspergillus ficuum AF-98. Bioresour. Technol. 99, 5938-5941.

Fortkamp, D., Knob, A., 2014. High xylanase production by Trichoderma viride using pineapple peel as substrate and its aplication in pulp biobleaching. Afr. J. Biotechnol. 13, 2248-2259. 
Guimarães, N.C.A., Sorgatto, M., Peixoto-Nogueira, S.C., Betini, J.H.A., Zanoelo, F.F., Marques, M.R., Polizeli, M.L.T.M., Giannesi, G.C., 2013. Xylanase production from Aspergillus japonicus var. aculeatus: production using agroindustrial residues and biobleaching effect on pulp. J. Biocatal. Biotransfor. 2, 1.

Hmida-Sayari, A., Taktek, S., Elgharbi, F., Bejar, S., 2012. Biochemical characterization, cloning and molecular modeling of a detergent and organic solvent-stable family 11 xylanase from the newly isolated Aspergillus niger US368 strain. Process Biochem. 47, 1839-1847.

Jimenez, C.R., Huang, L., Qiu, Y., Burlingame, A.L., 2001. In-gel digestion of proteins for MALDI-MS fingerprint mapping. Curr. Protein Pept. Sci. 16, 4.1-16.4.5.

Juturu, V., Wu, J.C., 2012. Microbial xylanases: engineering, production and industrial applications. Biotechnol. Adv. 30, 1219-1227.

Kearse, M., Moir, R., Wilson, A., Stones-Havas, S., Cheung, M., Sturrock, S., Buxton, S., Cooper, A., Markowitz, S., Duran, C., Thierer, T., Ashton, B., Mentjies, P., Drummond, A., 2012. Geneious Basic: an integrated and extendable desktop software platform for the organization and analysis of sequence data. Bioinformatics 28 (12), 1647-1649.

Knob, A., Carmona, A.C., 2010. Purification and characterization of two extracellular xylanases from Penicillium sclerotiorum: a novel acidophilic xylanase. Appl. Biochem. Biotechnol. 162, 429-443.

Krengel, U., Dijkstra, B.W., 1996. Three-dimensional structure of Endo-1,4- $\beta$-xylanase I from Aspergillus niger: molecular basis for its low pH optimum. J. Mol. Biol. 263, $70-78$.

Krisana, A., Rutchadaporn, S., Jarupan, G., Lily, E., Sutipa, T., Kanyawim, K., 2005. Endo-1,4- $\beta$-xylanase from Aspergillus $c f$. Niger BCC14405 isolated in Thailand: purification, characterization and gene isolation. Biochem. Mol. Biol. 38, 17-23.

Kulkarni, N., Shendye, A., Rao, M., 1999. Molecular and biotechnological aspects of xylanases. FEMS Microbiol 23, 411-456.

Laemmli, U.K., 1970. Cleavage of structural proteins during the assembly of the head of bacteriophage T4. Nature 227, 680-685.

Leone, F.A., Baranauskas, J.A., Furriel, R.P.M., Borin, I.A., 2005. SigrafW: an easy-to-use program for fitting enzyme kinetic data. Biochem. Mol. Biol. Educ. 33, 399-403.

Li, X.T., Jiang, Z.Q., Li, L.T., Yang, S.Q., Feng, W.Y., Fan, J.Y., Kusakabe, I., 2005. Characterization of a cellulase-free, neutral xylanase from Thermomyces lanuginosus CBS 288.54 and its biobleaching effect on wheat straw pulp. Bioresour. Technol. 96, 1370-1379.

Li, L., Tian, H., Cheng, Y., Jiang, Z., Yang, S., 2006. Purification and characterization of a thermostable cellulose-free xylanase from the newly isolated Paecilomyces thermophila. Enzym. Microb. Technol. 38, 780-787.

Li, P.J., Xia, J.L., Shan, Y., Nie, Z.Y., 2015. Comparative study of multi-enzyme production from typical agro-industrial residues and ultrasound-assisted extraction of crude enzyme in fermentation with Aspergillus japonicus PJ01. Bioproc. Biosyst. Eng. 38, 2013-2022.

Linares-Pasten, J.A., Aronsson, A., Karlsson, E.N., 2018. Structural considerations on the use of endo-xylanases for the production of prebiotic xylooligosaccharides from biomass. Curr. Protein Pept. Sci. 19, 48-67.

Lowry, H., Rosebrough, N.J., Farr, A.L., Randal, R.J., 1951. Protein measurement with the Folin phenol reagent. J. Biol. Chem. 193, 267-275.

Lu, F., Lu, M., Lu, Z., Bie, X., Zhao, H., Wang, Y., 2008. Purification and characterization of xylanase from Aspergillus ficuum AF-98. Bioresour. Technol. 99, 5938-5941.

Manning, M., Colon, W., 2004. Structural basis of protein kinetic stability: resistance to sodium dodecyl sulfate suggests a central role for rigidity and a bias toward $\beta$-sheet structure. Biochem 43, 11248-11254.

McIlvaine, T.C., 1921. A buffer solution for colorimetric comparison. J. Biol. Chem. 49, 183-186.

Michelin, M., Peixoto-Nogueira, S.C., Betini, J.H.A., da Silva, T.M., Jorge, J.A., Terenzi, H.F., Polizeli, M.L.T.M., 2010. Production and properties of xylanases from Aspergillus terricola Marchal and Aspergillus ochraceus and their use in cellulose pulp Bleaching. Bioproc. Biosyst. Eng. 33, 813-882.

Miller, G.L., 1959. Use of dinitrosalicilic acid reagent for determination of reducing sugar. Anal. Chem. 31, 426-429.

Monclaro, A.V., Recalde, G.L., da Silva Jr., F.G., Freitas, S.M., Filho, E.X.F., 2019. Xylanase from Aspergillus tamarii shows different kinetic parameters and substrate specificity in the presence of ferulic acid. Enzym. Microb. Technol. 120, 16-22.

Monclaro, A.V., Aquino, E.N., Faria, R.F., Ricart, C.A.O., Freitas, S.M., Midorikawa, G.E. O., Miller, R.N.G., Michelin, M., Polizeli, M.L.T.M., Filho, E.X.F., 2016. Characterization of multiple xylanase forms from Aspergillus tamarii resistant to phenolic compounds. Mycosphere 1-14.

Nagar, S., Mittal, A., Gupta, V.K., 2012. Enzymatic clarification of fruit juices (apple, pineapple, and tomato) using purified Bacillus pumilus SV-85S xylanase. Biotechnol. Bioproc. Eng. 17, 1165-1175.

O'Toole, N., Min, X.J., Butler, G., Storms, R., Tsang, A., 2006. Sequence-based analysis of fungal secretomes. Applied Mycology and Biotechnology 6, 277-296.

Padma, P.N., Sravani, P., Misha, P., Sneha, N., Anuradha, K., 2017. Synergistic effect of multiple enzymes on apple juice clarification. Indian J. Sci. Technol. 10 (10), 1-5.

Paes, G., Berrin, J.-G., Beaugrand, J., 2012. GH11 xylanases: structure/function/ properties relationships and applications. Biotechnol. Adv. 30, 564-592.

Pal, A., Khanum, F., 2011. Purification of xylanase from Aspergillus niger DFR-5: individual and interactive effect of temperature and $\mathrm{pH}$ on its stability. Process Biochem. 46, 879-887.

Peng, F., Peng, P., Xu, P., Sun, R.C., 2012. Fractional purification and bioconversion of hemicelluloses. Biotechnol. Adv. 30, 879-903.

Polizeli, M.L.T.M., Rizzatti, A.C.S., Monti, R., Terenzi, H.F., Jorge, J.A., Amorim, D.S., 2005. Xylanases from fungi: properties and industrial applications. Appl. Microbiol. Biotechnol. 67, 577-591.
Raja, H.F., Miller, A.N., Pearce, C.J., Oberlies, N.H., 2017. Fungal identification using molecular tools: a primer for the natural products research community. J. Nat. Prod. 80, 756-770.

Redgwell, R.J., Michieli, J.-H., Fischer, M., Reymond, S., Nicolas, P., Sievert, D., 2001 Xylanase induced changes to water and alkali-extractable arabinoxylans in wheat flour: their role in lowering batter viscosity. J. Cereal Sci. 33, 83-96.

Reis, D.S., Costa, M.A.F., Peralta, R.M., 2003. Xylanase produced by a wild strain of Aspergillus nidulans. Acta Sci. Biol. Sci. 25, 221-225.

Rizzatti, A.C.S., Sandrim, V.C., Jorge, J.A., Terenzi, H.F., Polizeli, M.L.T.M., 2004. Influence of temperature on the properties of xylanolytic enzymes of the thermotolerant fungus Aspergillus phoenicis. J. Ind. Microbiol. Biotechnol. 31, 88-93.

Rizzatti, A.C.S., Jorge, J.A., Terenzi, H.F., Rechia, C.G.V., Polizeli, M.L.T.M., 2001. Purification and properties of a thermostable extracellular $\beta$-xylosidase produced by thermotolerant Aspergillus phoenicis. J. Ind. Microbiol. Biotechnol. 26, 156-160.

Rosmine, E., Sainjan, N.C., Silvester, R., Alikkunju, A., Varghese, S.A., 2017. Statistical optimization of xylanase production by estuarine Streptomyces sp. and its application in clarification of fruit juice. J. Genet. Eng. Biotechnol. 15, 393-401.

Saha, B.C., 2002. Production, purification and properties of xylanase from a newly isolated Fusarium proliferatum. Process Biochem. 37, 1279-1284.

Samanta, A.K., Jayapal, N., Jayaram, C., Roy, S., Kolte, A.P., Senani, S., Sridhar, M., 2015. Xylooligosaccharides as prebiotics from agricultural by-products: production and applications. Bioact. Carbohydr. Dietary Fibre 5, 62-71.

Sandrim, V.C., Rizzatti, A.C.S., Terenzi, H.F., Jorge, J.A., Milagres, A.M.F., Polizeli, M.L. T.M., 2005. Purification and biochemical characterization of two xylanases produced by Aspergillus caespitosus and their potential for kraft pulp bleaching. Process Biochem. 40, 1823-1828.

Seemakram, W., Boonrung, S., Katekaew, S., Aimi, T., Boonlue, S., 2016. Purification and characterization of low molecular weight alkaline xylanase from Neosartorya tatenoi KKU-CLB-3-2-4-1. Mycoscience 57 (5), 326-333.

Sharma, M., Chadha, B.S., Saini, H.S., 2010. Purification and characterization of two thermostable xylanases from Malbranchea flava active under alkaline conditions. Bioresour. Technol. 101, 8834-8842.

Sharma, P.K., 2017. Xylanases current and future perspectives: a review. J. New Biol. Rep. 6 (1), 12-22.

Silva, P.O., Guimarães, N.C.A., Peixoto-Nogueira, S.C., Betini, J.H., Marchetti, C.R., Zanoelo, F.F., Polizeli, M.L.T.M., Marques, M.R., Giannesi, G.C., 2015. Production of cellulase-free xylanase by Aspergillus flavus: effect of polyols on the thermostability and its application on cellulose pulp biobleaching. Afr. J. Biotechnol. 14 (52), 3368-3373.

Silva, L.A.O., Terrasan, C.R.F., Carmona, E.C., 2015. Purification and characterization of xylanases from Trichoderma inhamatum. Electron. J. Biotechnol. 18, 307-313.

Sorgatto, M., Guimarães, N.C.A., Zanoelo, F.F., Marques, M.R., Peixoto-Nogueira, S.C., Giannesi, G.C., 2012. Purification and characterization of an extracellular xylanase produced by the endophytic fungus, Aspergillus terreus, grown in submerged fermentation. J. Biocatal. Biotransfor. 11 (32), 8076-8084.

Subramaniyan, S., Prema, P., 2002. Biotechnology of microbial xylanases, enzymology, molecular biology, and application. Crit. Rev. Biotechnol. 22, 33-64.

Teixeira, R.S.S., Siqueira, F.G., Sousa, M.V., Ferreira-Filho, E.X., Bom, E.P.S., 2010. Purification and characterization studies of a thermostable $\beta$-xylanase from Aspergillus awamori. J. Ind. Microbiol. Biotechnol. 37, 1041-1051.

Tison, M.C., Andre-Leroux, G., Lafond, M., Georis, J., Juge, N., Berrin, J.G., 2009. Molecular determinants of substrate and inhibitor specificities of the Penicillium griseofulvum family 11 xylanases. Biochim. Biophys. Acta Protein Proteonomics $1794,438-445$.

Tochi, B.N., Wang, Z., Xu, S.Y., Zhang, W., 2009. The influence of a pectinase and pectinase/hemicellulases enzyme preparations on percentage pineapple juice recovery, particulates and sensory attributes. Pak. J. Nutr. 8, 1184-1189.

Uday, U.S.P., Majumdar, R., Tiwari, O.N., Mishra, U., Mondal, A., Bandyopadhyay, T.K., Bhunia, B., 2017. Isolation, screening and characterization of a novel extracellular xylanase from Aspergillus niger (KP874102.1) and its application in orange peel hydrolysis. Int. J. Biol. Macromol. 105, 401-409.

Vandermarliere, E., Bourgois, T.M., Rombouts, S., Van Campenhout, S., Volckaert, G., Strelkov, S.V., Delcour, J.A., Rabijns, A., Courtin, C.M., 2008. Crystallographic analysis shows substrate binding at the 3 to 1 active-site subsites and at the surface of glycoside hydrolase family 11 endo-1,4- $\beta$-xylanases. Biochem. J. 410, 71-79.

Vitcosque, G.L., Ribeiro, L.F.C., Lucas, R.C., Silva, T.M., Ribeiro, L.F., Damasio, A.R.L., Farinas, C.S., Gonçalves, A.Z.L., Buckeridge, M.S., Jorge, J.A., Polizeli, M.L.T.M., 2016. The functional properties of a xyloglucanase (GH12) of Aspergillus terreus expressed in Aspergillus nidulans may increase performance of biomass degradation. Appl. Microbiol. Biotechnol. 100, 9133-9144.

Walia, A., Guleria, S., Mehta, P., Chauhan, A., Parkash, J., 2017. Microbial xylanases and their industrial application in pulp and paper biobleaching: a review. 3 Biotech 7 , 11.

Wallace, G., Fry, S.C., 1999. Action of diverse peroxidases and laccases on six cell wallrelated phenolic compounds. Phytochemistry 52, 769-773.

Will, F., Bauckhage, K., Dietrich, H., 2000. Apple pomace liquefaction with pectinases and cellulases: analytical data of the corresponding juices. Eur. Food Res. Technol. 211, 291-297.

Wu, H., Cheng, X., Zhu, Y., Zeng, W., Chen, G., Liang, Z., 2018. Purification and characterization of a cellulase-free, thermostable endo-xylanase from Streptomyces 
griseorubens LH-3 and its use in biobleaching on eucalyptus kraft pulp. J. Biosci. Bioeng. 125, 46-51.

Yegin, S., 2017. Single-step purification and characterization of an extreme halophilic ethanol tolerant and acidophilic xylanase from Aureobasidium pullulans NRRL Y2311-1 with application potential in the food industry. Food Chem. 221, 67-75.
Zimbardi, A.L., Sehn, A.C., Meleiro, L.P., Souza, F.H.M., Masui, D.C., Nozawa, M.S.F., Guimaraes, L.H.S., Jorge, J.A., Furriel, R.P.M., 2013. Optimization of $\beta$-glucosidase, â-xylosidase and xylanase production by Colletotrichum graminicola under Solid-State Fermentation and application in raw sugarcane trash saccharification. Int. J. Mol.

Sci. 14, 2875-2902. 